\title{
Negative Sense ssRNA Virus
}

National Cancer Institute

\section{Source}

National Cancer Institute. Negative Sense ssRNA Virus. NCI Thesaurus. Code C14346.

A single stranded RNA virus where the RNA strand is the complement of a mRNA. 